\title{
Effects of prolonged shading stress on growth and survival of seagrass Posidonia australis in Jervis Bay, New South Wales, Australia
}

\author{
J. Fitzpatrick*, H. Kirkman \\ CSIRO Division of Fisheries, PO Box 20, North Beach, Western Australia 6020, Australia
}

\begin{abstract}
Experimental shading reduced the light reaching a shallow Posidonia australis meadow in Jervis Bay, New South Wales, Australia, to less than 10\% of incident light. Shaded seagrass had significantly lower leaf growth rate, shoot density, shoot weight and epiphyte weight than seagrass in control plots. The structure of the epiphyte community also changed under shade as the fleshy macroalgae disappeared during the first month of shading and the leaves were dominated by encrusting invertebrates. The magnitude of the decrease in shoot number and leaf growth varied among 3 experiments at different times of year. Shading in early summer had a more severe effect on the seagrass than shad ing at the end of summer. There was no significant recovery of $P$. australis in the shaded plots during 17 mo following removal of the shades.
\end{abstract}

KEY WORDS: Posidonia australis - Seagrass · Shading Light $\cdot$ Growth $\cdot$ Shoot density

\section{INTRODUCTION}

The seagrass Posidonia australis (Hook. f.) is widely distributed along the southern coast of Australia (Kuo \& McComb 1979, West et al. 1985). In New South Wales, it is generally confined to shallow water $<5 \mathrm{~m}$ deep) in estuaries and sheltered embayments (West et al. 1985, Fitzpatrick pers. obs.). In Jervis Bay, New South Wales, however, $P$. australis commonly grows to a depth of 6 to $7 \mathrm{~m}$, and extends to $10 \mathrm{~m}$ in some places The ability of $P$. australis to grow at greater depths in Jervis Bay than in other areas on the New South Wales coast may be related to the high water clarity in this bay. The depth distributions of seagrasses have been linked to the light-attenuating properties of the water in which they grow (Backman \& Barilotti 1976, Beer \& Waisel 1982, Dennison \& Alberte 1985, Dennison 1987. Larkum \& den Hartog 1989, Fourqurean \& Zieman 1991). It follows that if the depth distribution of $P$. australis is affected by water clarity, then a decrease in water clarity in Jervis Bay can be expected to reduce

\footnotetext{
•E-mail: jeremy.fitzpatrick@per.ml.csiro.au
}

the health or extent of $P$. australis meadows in the bay. Changes to the meadows are also likely to affect the associated flora and fauna. For example, epiphytes growing on the leaves are likely to be affected by reduced light. At natural densities, epiphytes are an important component of seagrass assemblages, as primary producers and habitat, and changes to their community structure may have impacts on the greater seagrass community.

Physical and biotic factors have the potential to severely reduce the amount of light reaching the seagrasses in Jervis Bay for prolonged periods. Proposals to establish a naval fleet base and an armaments depot in the bay call for dredging to establish and maintain access channels for large ships. Dredging increases water turbidity while the dredging is in progress, and the effect is prolonged when the dredge spoils are resuspended by wave action (Rogers 1990, Onuf 1994). In Laguna Madre, Texas, USA, dredging reduced light reaching the sea bed at $2 \mathrm{~m}$ depth to $3 \%$ of the surface light for 1 to 3 mo after dredging and to $5 \%$ for 11 to 15 mo after dredging (Onuf 1994). Light attenuation in Jervis Bay may also increase due to turbidity from erosion in the catchment areas of the creeks running 
into the bay, and eutrophication. Eutrophication promotes the growth of algae which can grow very rapidly and block the light from underlying seagrasses. For example, in a mat of free-living Cladophora montagneana, less than $1 \%$ of light reaching the mat penetrated more than $1 \mathrm{~cm}$ into it /Gordon \& McComb 1989). Shading due to excessive growth of epiphytes or free-living macroalgae, has been the suggested cause of major declines of Posidonia spp. in Cockburn Sound (Cambridge 1979, Cambridge et al. 1986, Silberstein et al. 1986, Shepherd et al. 1989) and in Albany Harbours (Bastyan 1986, Gordon et al. 1994) in Western Australia and around Adelaide, South Australia (Neverauskus 1987)

In addition to studies which have demonstrated correlation between reduced light and seagrass decline (Cambridge et al. 1986, Silberstein et al. 1986, Giesen et al. $1990 \mathrm{a}$, b), there have been some manipulative field experiments which investigated the relationships between the distribution and growth of seagrasses and light (Backman \& Barilotti 1976, Congdon \& McComb 1979, Dennison \& Alberte 1982, 1985, Bulthuis 1983, 1984, Neverauskas 1988, Gordon et al. 1994). These studies have provided evidence of causal relationships between light reduction and reduction in the growth and biomass of seagrasses. However, these relationships were complicated by variation in the rate of response, depending on the time of year and the level of shading. For example, the response of Heterozostera tasmanica [(Marten ex Aschers.) den Hartog] to shading stress was more rapid in summer than in winter, and increased with the severity of the shading (Bulthuis 1983). The response of Posidonia sinuosa (Cambridge and Kuo) was also related to the severity of the shading (Gordon et al. 1994).

Field studies in Albany Harbours demonstrated that Posidonia sinuosa is adversely affected by long-term light reduction (Gordon et al. 1994). Within $104 \mathrm{~d}$ (3.5 mo) of shading to 1 to $20 \%$ of ambient light, the shoot density and productivity of shaded $P$. sinuosa was significantly less than that of controls (Gordon et al. 1994). Incubation chamber studies of the photosynthesis versus irradiance characteristics of 'whole plants' indicate that $P$. australis has a slightly higher compensation irradiance point $\left(I_{\mathrm{c}}\right)$ and a much higher saturation irradiance point $\left(I_{k}\right)$ than $P$. sinuosa: at $18^{\circ} \mathrm{C}$,

and

$$
\text { P. australis } \begin{aligned}
I_{c} & =25 \pm 1.2(\mathrm{SE}) \mu \mathrm{E} \mathrm{m} \mathrm{m}^{-2} \mathrm{~s}^{-1}, \\
I_{k} & =90 \pm 4.1 \mu \mathrm{E} \mathrm{m}^{-2} \mathrm{~s}^{-1}
\end{aligned}
$$

$$
\text { P. sinuosa } \begin{aligned}
I_{\mathrm{c}} & =24 \pm 1.6(\mathrm{SE}) \mu \mathrm{E} \mathrm{m} \mathrm{m}^{-2} \mathrm{~s}^{-1}, \\
I_{k} & =55 \pm 3.2 \mu \mathrm{E} \mathrm{m}^{-2} \mathrm{~s}^{-1}
\end{aligned}
$$

(Masini et al. 1995). These data indicate that $P$. australis requires considerably more light than $P$. sinuosa (Masini et al. 1995) and is therefore likely to be more susceptible to light reduction than $P$ sinuosa. This susceptibility has important implications for management of Posidonia spp. meadows under threat from deteriorating water quality. The response of $P$. australis to shading stress has not been investigated in the field

The present study is the first experimental investigation of the response of Posidonia australis and its epiphytes to light reduction in the field. The aims of this study were to compare the leaf growth rates, shoot densities and shoot weights of $P$. australis shaded to below its compensation irradiance with those of unshaded seagrass, to monitor recovery following return to full light, and to follow changes in the epiphyte communities living on seagrass leaves in response to reduced light.

\section{MATERIALS AND METHODS}

Study site. Experiments were conducted in the shallow (3 to $4 \mathrm{~m}$ deep) part of a Posidonia australis meadow at Seamans Beach in Jervis Bay (Fig. 1). This site was selected because it was closed to seine fishing and boating, and because it was protected from the strong northeasterly winds prevalent during summer.

Experimental shades. Steel frames $(1.5 \times 1.5 \times 1.5 \mathrm{~m})$ were covered with black or clear plastic $(200$ to $300 \mu \mathrm{m}$ polyethylene builders' film) or shadecloth. The legs of the covered frames were pushed into the sediment until the shading material was at about the same level as the tops of the seagrass leaves (Fig. 2). Black plastic and shadecloth were intended to reduce light to less than that required by the seagrass for survival (less than $I_{c}$ for Posidonia australis). Clear plastic was intended to have minimal effect on light, but mimic the effects of the black plastic on water movement. The plastic was only used in the pilot study because it was often torn during rough weather, especially where it was fastened to a frame, and required frequent repair. The clear plastic was also quickly fouled by epiphytic algae and invertebrates and required frequent clean-

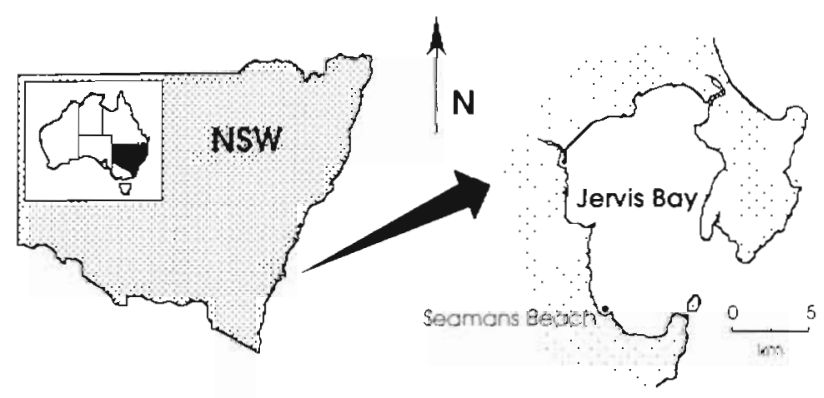

Fig. 1 Experimental site at Seamans Beach in Jervis Bay, New South Wales, Australia 


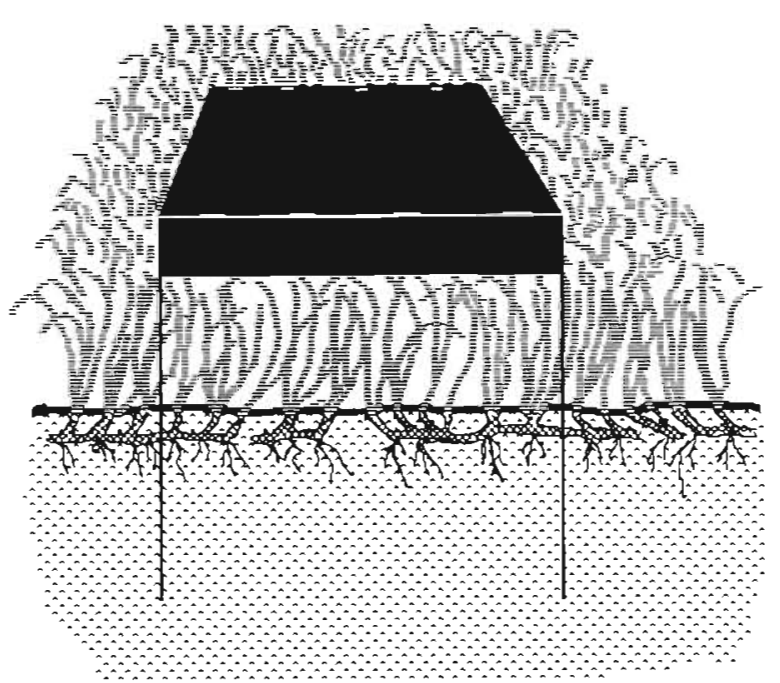

Fig. 2. Shading frame. Legs of the frames were pushed into the sediment until the sides were level with the tops of the seagrass leaves

ing. Shadecloth ( $90 \%$ light reduction) was used in the later experiments as it was much tougher and, in combination with an improved frame construction, proved more resistant to damage.

Light under the shades. To determine the pattern of light reduction caused by the shades, we measured light in horizontal profiles under 1 or 2 shades in February 1990. September 1990 and March 1991. Photosynthetically active radiation (PAR: 400 to $700 \mathrm{~nm}$ ) was measured mid-morning on clear sunny days, using a CSIRO/YeoKal Model 606 submersible data logger fitted with 2 Licor $4 \pi$ underwater quantum (PAR) sensors. The sensors were placed side by side in the seagrass meadow to check that they were similarly calibrated. Simultaneous light readings were taken every $3 \mathrm{~s}$ for about 5 min. The 2 adjacent sensors measured similar incident light levels at the top of the seagrass canopy. Although there were differences between the 2 sensors, the periods of difference lasted less than $30 \mathrm{~s}$ and were probably due to movement of the seagrass leaves around the sensors. During profiles, one sensor measured light under a shade at the same time that the other measured light in the adjacent unshaded seagrass meadow. The difference between the readings was attributed to light attenuation by the shade

Light profiles under the black plastic and shadecloth shades indicated that light got in around the edge of the shades, creating a partially shaded border about $25 \mathrm{~cm}$ wide (Fig. 3). Inside this border, the light was generally less than $20 \mu \mathrm{E} \mathrm{m} \mathrm{m}^{-2} \mathrm{~s}^{-1}$, which is below the theoretical compensation point for Posi- donia australis and about 1 to $10 \%$ of the incident light in the meadow. The shadecloth was quickly fouled and took on light-attenuating properties similar to black plastic (90 to $99 \%$ light reduction). Plastic mesh is a neutral density filter, i.e. it reduces the amount of light reaching the sea bed without changing the spectral characteristics of the light (Bulthuis 1983). Clean, clear plastic had little effect on the intensity of light reaching the seagrass (Fig. 3). Before cleaning, clear plastic fouled by epiphytes reduced the light to about $70 \%$ of that in the adjacent meadow, but the light was still much higher than the $I_{c}$ of $P$. australis. The light in the meadow nearby remained fairly constant during the profiling process. The light under the clear plastic was expected to be sufficient for the plants to function normally, whereas light under the black plastic was expected to be too low for photosynthetic carbon gain.

Data collection and analysis. Leaf growth rate was measured by the hole-punch method (Kirkman \& Reid 1979. Dennison 1990). In each plot, 25 shoots were harvested 10 to $14 \mathrm{~d}$ after punching, and processed in the laboratory. All epiphytes were scraped off the leaves with a razor blade. Punched shoots were cut through the centre of the hole in the dead base and in the individual leaves. The section of leaf between the 2 cuts was new growth from the 10 to $14 \mathrm{~d}$ period. The epiphytes, segments of new growth (growth increment) and remaining portions of the shoots from each sample were oven-dried to constant weight. Growth rates (mg dry wt shoot ${ }^{-1} \mathrm{~d}^{-1}$ ) were derived by dividing the growth increment by the number of days between punching and harvesting (usually 10) and by the number of shoots in a sample (usually 25). Epiphyte biomass was standardised for differences in the number of shoots and the area of leaf available by dividing it by the leaf biomass. Shoot densities were measured by counting all shoots with green leaves within one

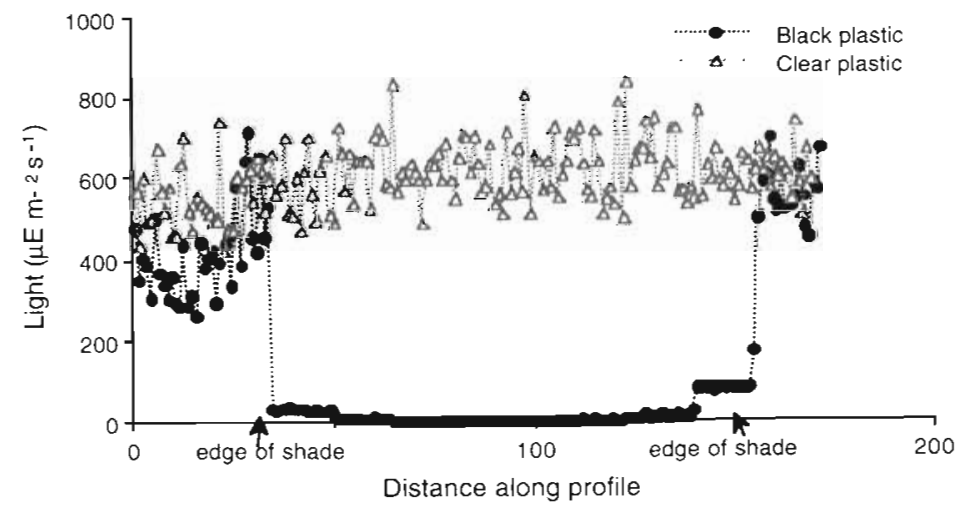

Fig. 3. Profiles of light from outside (ambient light) and under shade frames covered with clear plastic and black plastic in the seagrass meadow at Seamans Beach. Ambient light levels are those before and after the edges of the shades. Distance in $\mathrm{cm}$ 
$0.0625 \mathrm{~m}^{2}(0.25 \times 0.25 \mathrm{~m})$ quadrat under each shade and in each control plot.

The experiments at Seamans Beach were set up in a series of blocks covering most of the meadow. Shading treatments were randomly applied within the experimental blocks and the response variables were sampled within each block. In the shading experiments, where shoots were counted in several quadrats in each block, replicate quadrats were treated as another blocking factor and nested within blocks for analysis. Prior to ANOVA, data were tested for homogeneity of variances using Cochran's test. Heteroscedastic data were transformed, in order to normalise their distribution and standardise their variances, and then re-tested for homoscedasticity. Blocked, partial-factorial ANOVA (Cochran \& Cox 1957) of the homoscedastic data was conducted using super-ANOVA (Abacus Concepts, Inc.). Student-Newman-Keuls (SNK) multiple comparisons tests were used to test the significance of differences between means for significant terms in the ANOVAs

Pilot study. Posidonia oceanica [(L.) Delile] can transfer photosynthates between shoots on the same rhizome (Libes \& Boudouresque 1987). The possibility of translocation of photosynthates from unshaded shoots to shaded shoots, and hence a buffering of the effects of shading, has led experimenters to cut the rhizomes around their shaded plots (Neverauskas 1988, Gordon et al. 1994). We examined the effects of cutting rhizomes and the physical presence of the shade structure on the growth of $P$. australis leaves in a pilot study between September and December 1990.

Five sets (blocks) of treatments were established in the seagrass meadow at Seamans Beach. In each of the 5 blocks, 6 patches of seagrass $(1.5 \times 1.5 \mathrm{~m})$ were covered with either black plastic $(n=2)$, clear plastic $(n=$ 2 ) or left unshaded $(n=2)$. The 6 patches were set up in a regular pattern within the blocks, with about 2 to $3 \mathrm{~m}$ between each patch and about $15 \mathrm{~m}$ between each block. Treatments were randomly assigned to patches. The rhizomes along the edge of half of the patches (i.e. 1 per treatment, 3 per block) were cut to a depth of at least $15 \mathrm{~cm}$. We measured the growth rate of leaves on shoots within the zone of full shading under the frames and in the control plots at the end of $3 \mathrm{mo}$. It was not always possible to find 25 shoots under a black plastic shade after 3 mo of shading; in such cases growth was calculated using all of the shoots that were available Growth in patches that had been cut around the edge was compared with growth in patches that had not been cut, to examine the importance of photosynthate translocation in sustaining seagrass under the shades. Growth under clear plastic was compared with growth under black plastic to measure the effect of the physical presence of the shade structure. The plastic on all frames was cleaned at least weekly inside and outside to remove encrusting algae, invertebrates and detritus which attenuate light.

The leaf growth rate data from the pilot study were homoscedastic at $\alpha=0.05$ (Cochran's test), hence, transformation was not necessary. A blocked, partialfactorial ANOVA revealed significant variation due to shading $(\mathrm{p}=0.0001)$. The growth of the Posidonia australis leaves under black plastic was significantly lower than the growth in control areas and under clear plastic (SNK, $p=0.05$; Fig. 4). However, cutting rhizomes had no effect on leaf growth in either treatment or in the controls ( $p=0.4609$; Fig. 4). This indicates that the translocation of photosynthates from shoots outside the shades to those under the shades was not sufficient to maintain normal rates of leaf growth in the shaded $P$. australis. Leaf growth of the seagrass under clear plastic shades was no different to the growth of seagrass in control areas (SNK, $p=0.05$; Fig. 4). This indicates that seagrass growth rates were not affected by the physical presence of a shading structure. Apart from minor erosion around the edge of the frames, there was no sign that the frames affected the shoots in any way other than shading. Controls for the hydrological or other effects of the shades on leaf growth and shoot density were considered unnecessary in subsequent experiments.

Expt 1: Rate of response to shading stress. The pilot study showed that growth of shaded Posidonia australis leaves was severely reduced (by $\sim 80 \%$; Fig. 4) after 3 mo of shading. Expt 1 was designed to determine the rate of decline in leaf growth and shoot density, and changes in the epiphyte community during the first 3 mo of shading stress. We examined the rate of the decline in leaf growth due to shading stress at Seamans Beach in March 1991.

We placed 3 shades, covered in $90 \%$ shadecloth, in each of 5 separate blocks in the seagrass meadow at

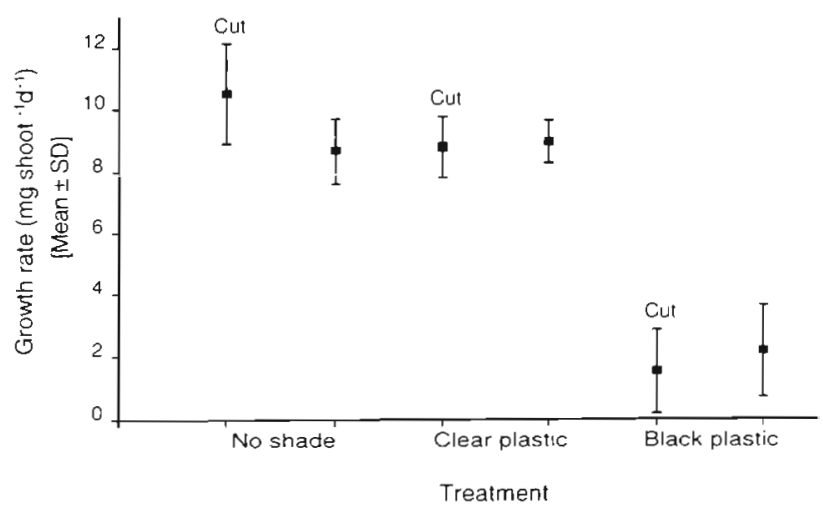

Fig. 4. Posidonia australis. Growth rate of seagrass leaves after 3 mo under black plastic shades, clear plastic shades and no shades. Cut: rhizomes around the edge of the patches were cut to a depth of $1.5 \mathrm{~cm}$ 
3 to $4 \mathrm{~m}$ depth. Frames were 2 to $10 \mathrm{~m}$ apart and blocks were about 5 to $10 \mathrm{~m}$ apart. We randomly selected 3 control patches of seagrass in each block. Leaf growth rates and shoot density were measured monthly within the fully shaded inner zone of 1 frame and in 1 control plot, in each block. Shoot densities were counted nondestructively using a $0.0625 \mathrm{~m}^{2}$ quadrat. Sampling different frames each month permitted 1 independent sample to be taken in each of the 3 months. Of the 25 punched shoots collected in the monthly samples 3 other parameters were also measured:

(1) Total shoot weight: the sum of the dry weights of the shoot bases (section of shoots below punched holes), the growth increment (section of leaves between the 2 holes) and the original leaf segments (section of leaves above punched holes).

(2) Epiphyte weight: dry weight of epiphytes scraped of the leaves divided by the total weight of the dried leaves. Epiphyte weights were thus standardised for the amount of leaf space available for colonization and growth. We compared the total area of leaves on each of 50 shoots with the dry weight of the leaves on the same shoots. At 3 different meadows in Jervis Bay, leaf area was significantly correlated with leaf weight $(\mathrm{p}=$ 0.54 to $0.90, \mathrm{n}=50, \alpha<0.01$ ).
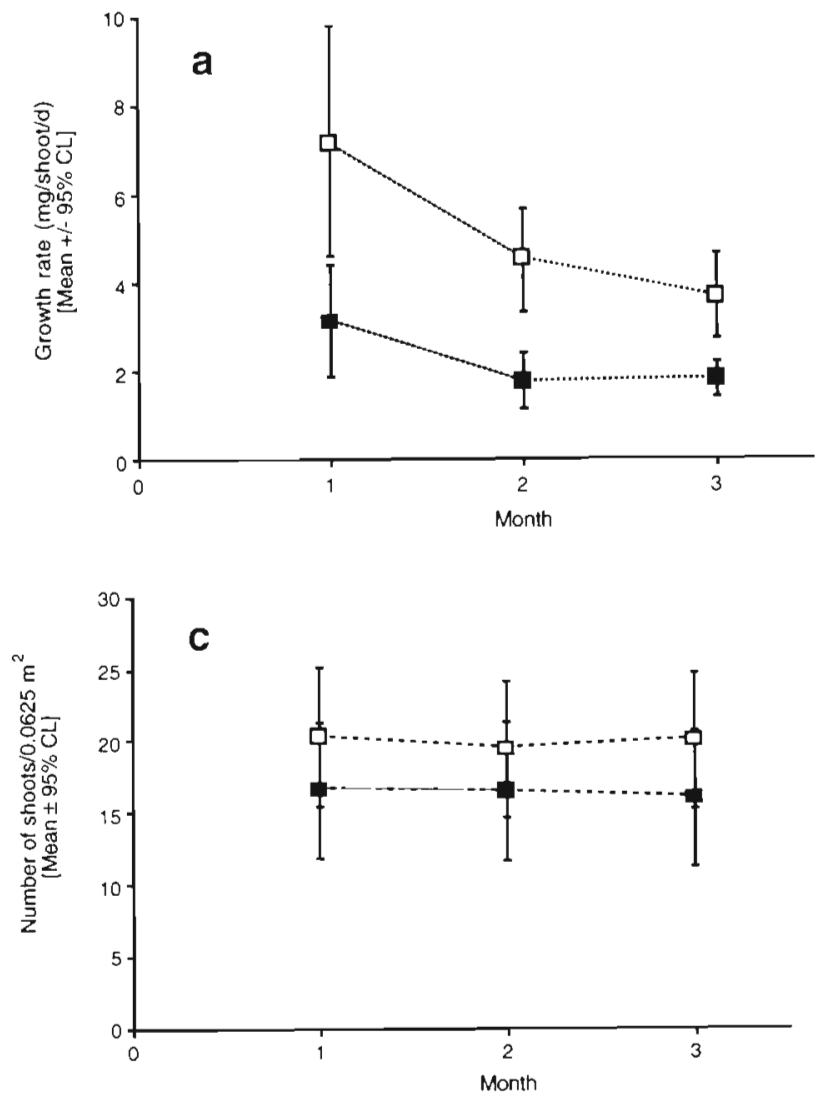

(3) Epiphyte types: the presence or absence of the 5 most common macroscopic taxa on the seagrass leaves: fleshy macroalgae, coralline algae, molluscs, worms and bryozoans.

Leaf growth, shoot weight, epiphyte weight and shoot density data from the 3 months were examined using blocked, partial-factorial ANOVA as described previously. In the ANOVAs, Time was treated as a random factor and Shading level as a fixed factor.

Expt 2: Recovery of shoot density after shading stress. Four frames covered in shadecloth, were placed in each of 5 blocks at 3 to $4 \mathrm{~m}$ depth in the Posidonia australis meadow at Seamans Beach in December 1990. A subset of the 4 frames was removed every 3 mo; i.e. within each block, all 4 frames were left on for $3 \mathrm{mo}, 3$ frames were left on for $6 \mathrm{mo}, 2$ frames were left on for 9 mo. Shoots were counted under the shades during the $9 \mathrm{mo}$ of shading. The recovery of shoot numbers following removal of the shade frames was monitored for 17 mo.

Temporal variation in the response to shading. Posidonia australis was shaded for about 3 mo during 3 different times of year during the pilot study and Expts 1 \& 2 . In the pilot study, seagrass was shaded with black plastic for 91 d from early September to
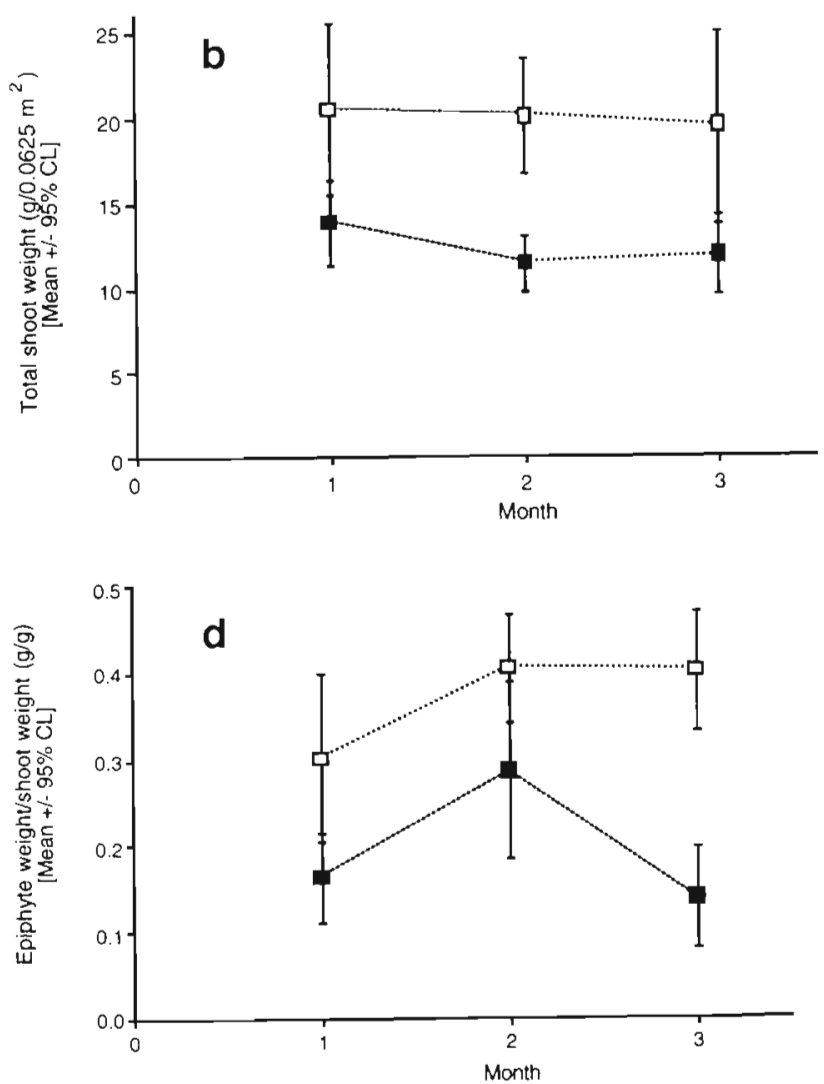

Fig. 5. Posidonia australis. (a) Leaf growth rate, (b) above-ground biomass, (c) shoot densities, and (d) standardised epiphyte biomass at monthly intervals during 3 mo of shading. (a) Unshaded control plots; (D) plots shaded under black plastic 
early December (spring). In Expt 2, seagrass was shaded with shadecloth for $95 \mathrm{~d}$ from early December to March (summer). In Expt 1, seagrass was shaded with shadecloth for $104 \mathrm{~d}$ from early March to June (late summer-autumn). Water temperatures at Hole in the Wall, a nearby site in Jervis Bay, ranged from a winter minimum of about $15^{\circ} \mathrm{C}$ to a summer maximum of about $24^{\circ} \mathrm{C}$ (CSIRO 1994). In each of these 3 experiments, we counted shoots under at least 1 shade and in at least 1 control plot in each of the 5 blocks. We compared the number of shoots in $0.0625 \mathrm{~m}^{2}$ quadrats after 3 mo shading in the 3 experiments. We also compared leaf growth after 3 mo in the pilot study with that in Expt 1.

\section{RESULTS}

\section{Expt 1: Rate of response to shading stress}

Leaf growth rate. Leaf growth rate data were heteroscedastic and $\log _{10}(x+1)$ transformation was necessary to achieve homoscedasticity $(\alpha=0.05)$. A blocked, partial-factorial analysis of variance indicated that growth varied significantly between shaded and unshaded areas and between months $(p=0.0001$ for both tests). Growth rates in the shaded plots were significantly reduced (SNK, p $=0.05$ ) to about $44 \%$ of those in control plots after 1 mo of shading and remained lower for the following $2 \mathrm{mo}$ (Fig. 5a). Growth decreased after the first month in both the control and shaded plots but was always significantly lower in shaded plots (SNK, p = 0.05; Fig. 5a).

Shoot weight. Total shoot weights (the pooled weight of 25 shoots) were calculated by adding the growth increment, the original shoot weight and the weight of the shoot base for each monthly sample. These data were homoscedastic $(\alpha=0.05)$ and hence no transformation was necessary. A blocked, partialfactorial analysis of variance revealed a significant difference in shoot weight due to shading $(p=0.0001)$. Shoot weights under the shades were significantly lower than in control plots (SNK, p $=0.05$, Fig. 5b). Shoot weights did not vary significantly between months $(p=0.2341)$, indicating that after the initial decrease, there was little further reduction in total shoot weight (Fig. 5b).

Shoot number. Shoot counts from March to June 1991 were homoscedastic at $\alpha=0.05$. A blocked, partial-factorial analysis of variance showed that shading significantly affected shoot numbers $(p=0.0073)$, but that time (the number of months) did not ( $p=0.9382$ ). The mean number of shoots with live leaves (data pooled over $3 \mathrm{mo}$ ) in a $0.0625 \mathrm{~m}^{2}$ quadrat was significantly lower $(\mathrm{SNK}, \mathrm{p}=0.05)$ in the shaded plots
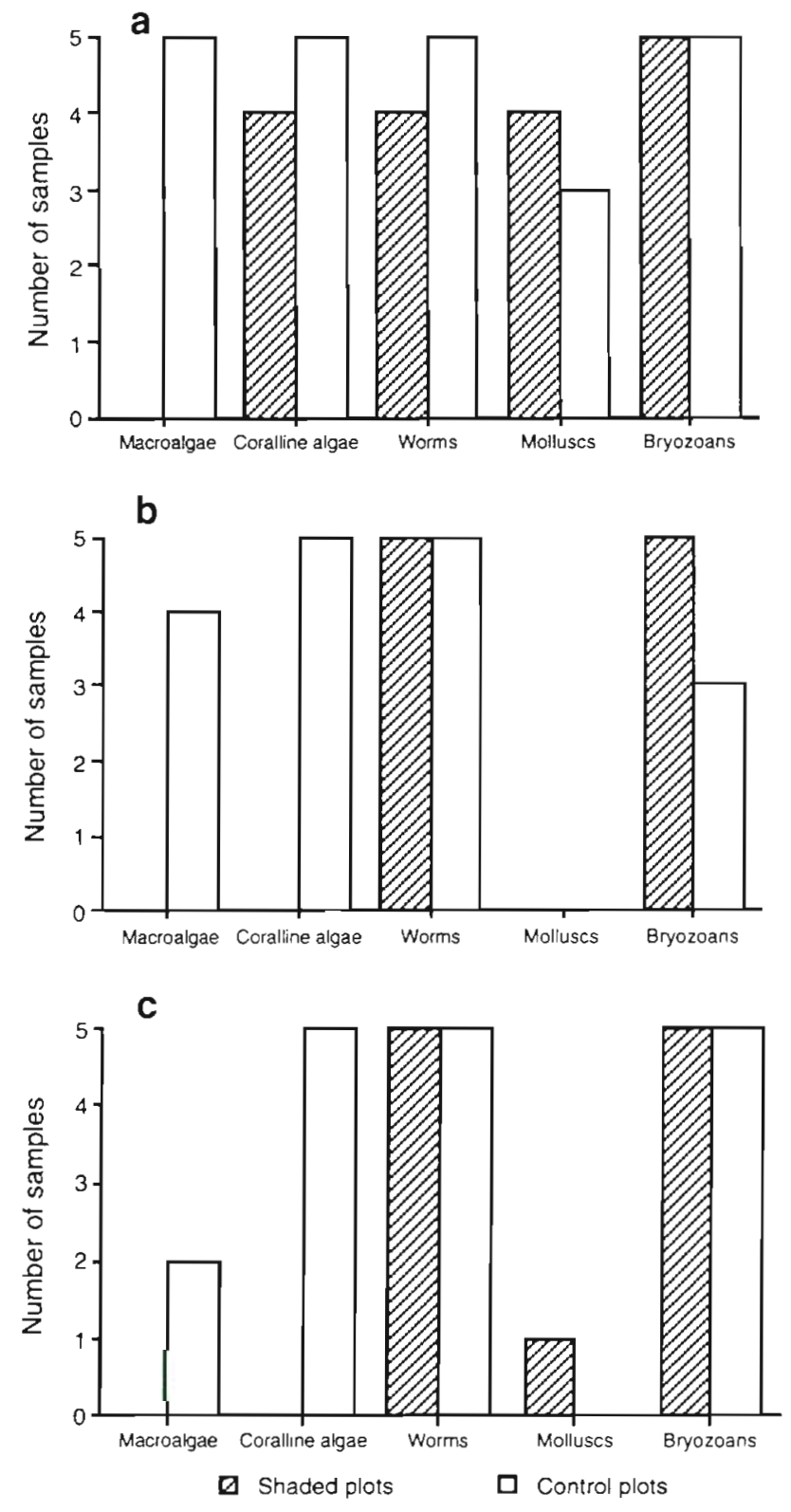

Fig. 6. Frequency of occurrence of 5 taxa growing epiphytically on Posidonia australis after (a) 1 mo of shading, (b) 2 mo of shading and (c) 3 mo of shading. Macroalgae: fleshy macroalgae coralline algae: resupinate and erect corallines; worms: tube-building polychaetes; molluscs: attached bivalves; bryozoans: resupinate and erect bryozoans. Control plots were in unshaded seagrass and shaded plots were under black shadecloth

(mean $=16.37, \mathrm{SD}=5.03)$ than in the control plots (mean $=19.90, \mathrm{SD}=5.16)$. The difference in shoot numbers between the shaded and control plots was evident after the first month, and the differences did not increase during the following $2 \mathrm{mo}$ (Fig 5c). However, shoot densities in shaded and unshaded plots did not differ significantly in any given month ( $\mathrm{SNK}, \mathrm{p}=0.05$ ). 


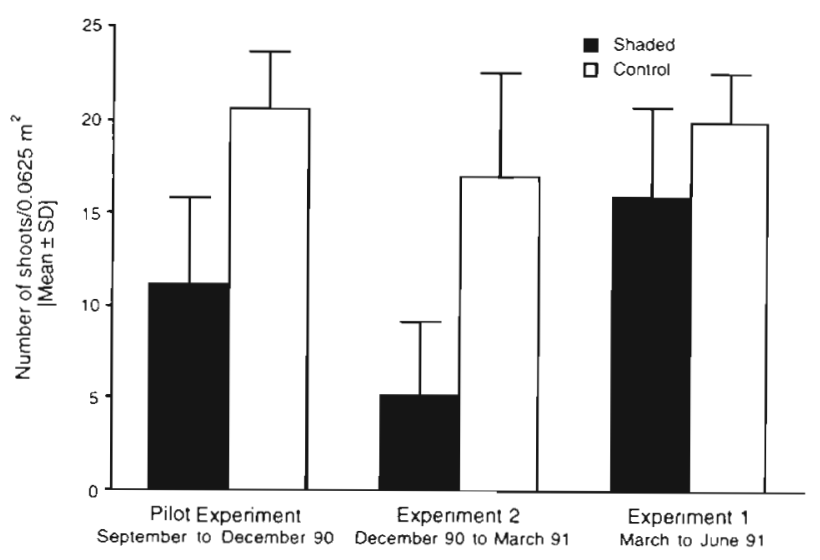

Fig. 7. Posidonia australis. Shoot densities after about 3 mo of shading in the 3 experiments at Seamans Beach. Control densities are from unshaded seagrass plots in the same meadow. Shading duration varied slightly between experiments: pilot study, 91 di Expt 1, 95 di Expt 2, 104 d

Epiphyte weight. Standardised epiphyte weight (epiphyte weight/shoot weight) data were homoscedastic at $\alpha=0.05$. A blocked, partial-factorial analysis of variance in the standardised epiphyte weight data revealed a significant Month $\times$ Shade interaction $(p=0.0349)$. This indicated that epiphyte biomass in both shaded and unshaded plots changed with time, but that the pattern differed between the treatments. Epiphyte biomass was significantly lower (SNK, p = 0.05 ) in shaded plots than in unshaded plots throughout the experiment and especially at the end (Fig. 5d). Epiphyte biomass increased under both treatments during the second month, but fell dramatically during the third month under shade (Fig. 5d). Under shade, the epiphyte community was dominated by invertebrates, especially bryozoans and tube-building worms, by the end of the second month (Fig. 6b). Fleshy

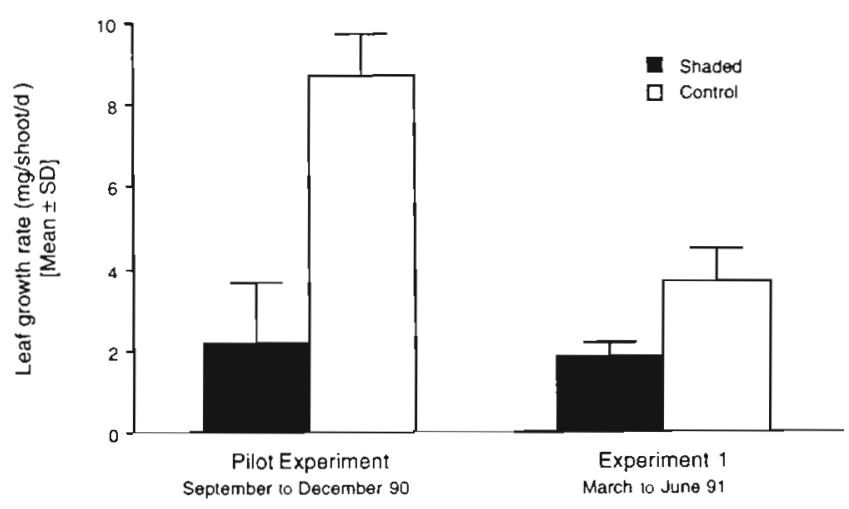

Fig. 8. Posidonia australis. Leaf growth rate after 3 mo of shading in 2 experiments at Seamans Beach. Control densities are from unshaded seagrass plots in the same meadow. Shading duration varied slightly between experiments: pilot study, 91 d; Expt 1, 95 d macroalgae completely disappeared from the seagrass leaves in the shaded plots during the first month of shading and the coralline algae disappeared during the second month; worms and bryozoans persisted for the entire 3 mo (Fig. 6). There was a small decrease in the number of control plot samples with macroalgae during the 3 mo.

\section{Temporal variation in the response to shading}

Shoot number. Shading for 3 mo significantly reduced the density of live seagrass shoots at all times of year (in all experiments). The effect of shading on shoot density was greatest between December 1990 and March 1991 (Expt 2) and least between March and June 1991 (Expt 1; Fig. 7).

Growth. From September to December 1990 (pilot study) and from March to June 1991, shading for 3 mo significantly reduced the growth of seagrass leaves. The effect of shading was similar in these 2 periods (Fig. 8)

\section{Expt 2: Recovery from shading stress}

Shoot numbers decreased as the length of the shading period increased (Fig. 9). After 3 mo of shading, shoot counts dropped to 0 under a few shades; by 8 mo shoot counts were 0 under most shades. We noticed dead rhizomes under shades after 9 mo.

Posidonia australis flowered in the control plots in August and October 1991. There were also a few flowers in the plots shaded for 3 mo and given 5 or 6 mo without shade to recover. However, no shoots flowered under the shades ( 8 and 9 mo shading) or in the plots shaded for 6 mo and given 2 or 3 mo to recover.

Posidonia australis shoot numbers de-creased or remained low following the removal of the shades. Shoot numbers in plots shaded for 3 mo continued to decrease slightly after the shades were removed (Fig. 9). Shoot numbers in plots shaded for 3, 6 or 9 mo remained very low until the final observation about 11 months after the last shades were removed (Fig. 9). At the time of the final observation in August 1992, the plots shaded for 3 mo had been given 17 mo to recover, but there was no recovery.

\section{DISCUSSION}

Posidonia australis leaf growth and shoot density rapidly responded to shading of 90 to $99 \%$. The growth rate of shaded $P$. australis leaves fell to less than $50 \%$ of that of controls after only 1 mo of shading in Expt 1. 


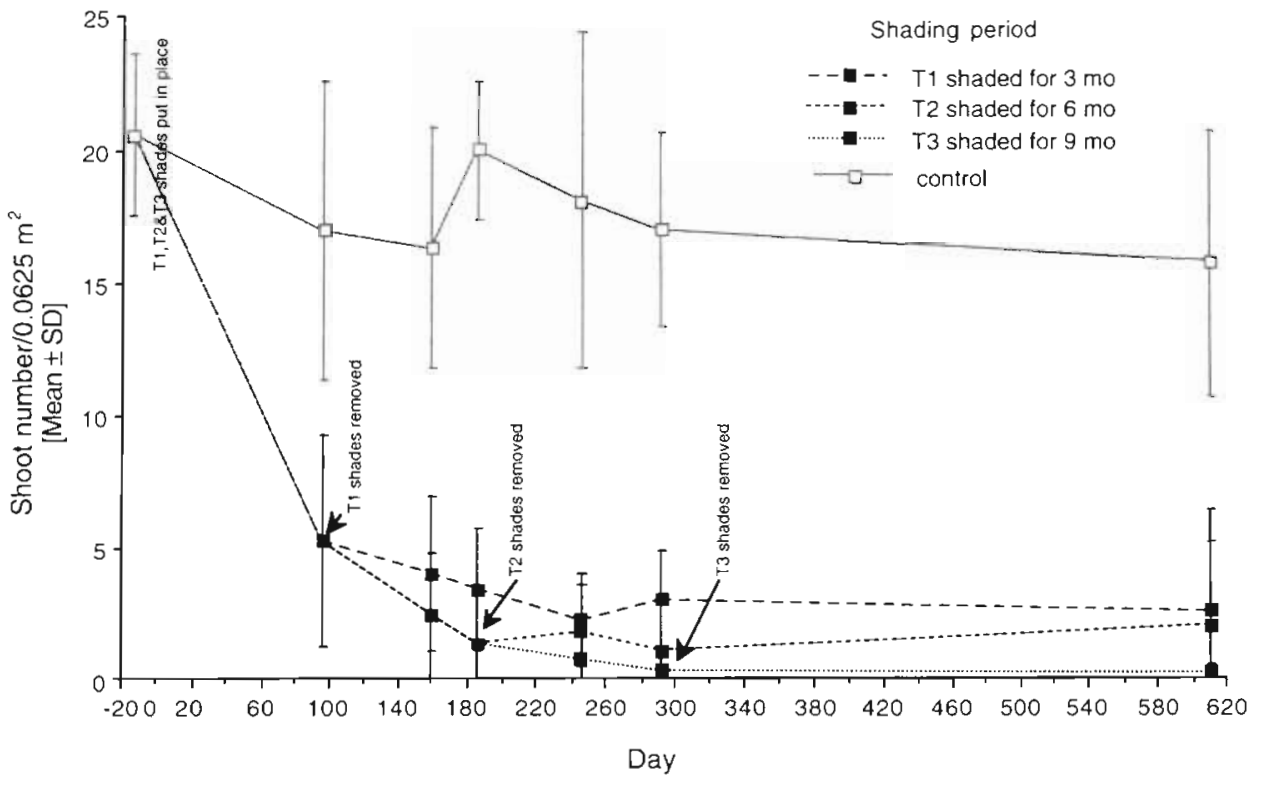

Fig. 9. Posidonia australis Shoot densities in Expt 2 at Seamans Beach. Seagrass was shaded for $3 \mathrm{mo}$ (T1), $6 \mathrm{mo}$ (T2) and 9 mo (T3) and allowed to recover for up to $17 \mathrm{mo}$ ( $\mathrm{T} 1$ on Day 611) after removal of the shades. Control densities are from unshaded seagrass plots in the same meadow
When the seagrass was shaded for $3 \mathrm{mo}$, the growth rate decreased further. However, growth in unshaded seagrass also decreased throughout Expt 1. This was probably the normal seasonal decline associated with the onset of winter. Even though leaf growth in the surrounding meadow declined naturally, the growth rate under the shades was always 50 to $60 \%$ lower. Shoot densities decreased significantly after $3 \mathrm{mo}$ in all experiments. The decrease in live shoot density and shoot weight under the shades resulted from loss of leaves and shoot death which was not evident in control plots outside the shades. The decrease in epiphyte biomass after the third month of shading was probably due to the loss of older seagrass leaves with the more mature epiphyte assemblages.

Shading also caused significant changes in the structure of the epiphyte assemblage growing on the posidonia australis leaves. Fleshy macroalgae appeared more susceptible to shading than the coralline algae, which survived more than 2 mo of shading. This suggests that even less than 2 mo of shading can lead to changes in the dominance patterns in the epiphyte assemblages. Prolonged shading led to loss of all macroalgae, but did not reduce the occurrence of encrusting bryozoans and polychaetes. Extended shading caused a shift in the macroscopic assemblage from a polytrophic assemblage to one dominated by heterotrophs. In addition to the change in the trophic metabolism and the consequent loss of primary productivity, the diversity of the assemblage may decrease. Macroalgal diversity fell dramatically due to shading, therefore the diversity of fauna dependent on the algae must also subsequently decrease.
Differences between experiments, in the severity of shoot decline due to shading, suggest that the response of Posidonia australis to shading varies with season. This is consistent with the prediction that, if rhizome storage materials are seasonally depleted and built up, the capacity of the rhizome reserves to buffer the rest of the plant during periods of stress also varies seasonally. Seasonal differences in the concentration of rhizome sugars have been demonstrated in other seagrass species. Starch reserves in the rhizomes of $P$. oceanica (Pirc 1985) and Zostera capricorni (Ascherson) (King \& Holland 1986) reach maximum concentrations in summer and minima in winter. Starch reserves also decrease during winter in $P$. sinuosa rhizomes (Gordon et al. 1992). Furthermore, shading led to depletion of rhizome sugars in $P$. sinuosa (Gordon et al. 1992). Therefore, if seagrass is shaded during the period when its rhizome stores are naturally depleted (at the end of winter), it is likely to exhaust its reserves quickly. Masini et al. (1990) suggested that shading stress during spring and early summer, when $P$. sinuosa takes advantage of high light levels to store carbohydrates, would be most detrimental to the survival of the meadow. If $P$. australis stores and uses rhizome reserves in a similar pattern to that observed for $P$. oceanica and predicted for $P$. sinuosa, its vulnerability to shading stress should be greatest in spring and early summer. Our data support this theory. In Jervis Bay, the decline in shoot densities was greatest in the December to March period and least in the March to June period.

In addition to fluctuations in rhizome reserves, changes in the ratio of photosynthetic production to respiratory loss (P:R) may affect the seagrasses' ability 
to withstand shading. If respiration rates increase in summer, then more light may be required for the increased productivity needed to maintain carbon gain. Bulthuis $(1983,1984)$ linked the more rapid loss of shaded Heterozostera tasmanica shoots in summer than in winter to higher respiration rates (due to higher water temperature), leading to a higher $I_{c}$ and hence increased light requirements.

The translocation of photosynthates through rhizomes has been demonstrated for Posidonia oceanica (Libes \& Boudouresque 1987). Therefore, we expected that shoots outside the shades might support growth of shoots under the shades through translocation. However, over a 3 mo period there was insufficient translocation of photosynthates to fully shaded shoots to prevent their death. It is possible that translocation to shaded shoots may be more important under less severe shading conditions or for shorter periods of shading.

The decline in leaf growth rates and shoot densities in our study was more rapid than that under 80 to $99 \%$ shade in Albany Harbours for $P$. sinuosa (Gordon et al. 1994). Carbohydrate and sugar reserves in the rhizomes of Posidonia sinuosa lasted relatively undiminished for about 5 mo under shading stress (Gordon et al. 1992). After about 1 yr of shading, about $50 \%$ of the carbohydrate and sugar reserves still remained (Gordon et al. 1992). Gordon et al. (1992) predicted collapse of the meadow within about $2 y \mathrm{r}$ at that level of shading. In the present study, many of the rhizomes were putrescent after 9 mo of shading, suggesting that their reserves had been used up. Our results suggest widescale mortality of shoots and rhizomes within 1 yr at 90 to $99 \%$ shading. The difference in the response times in the 2 studies is probably due to a combination of environmental factors and species-specific differences. $P$. australis may be more susceptible to low light stress than $P$. sinuosa, due to its higher compensation and saturation points (Masini et al. 1995). The deeper distribution of $P$. sinuosa compared with $P$. australis (Kirkman \& Kuo 1990) also supports this theory.

The effect of shading on Posidonia australis depends on the length of the shading period. In Expt 2, shoot densities continued to fall as the length of the shading period increased, until most of the $P$. australis shoots and rhizomes were dead. Severity of the light reduction probably also affects the rate and size of the response of $P$. australis to shading. This is true of other seagrasses; the effect of shading on $P$. sinuosa was greater under $99 \%$ shade than under $80 \%$ shade (Gordon et al. 1994), and the effect of shading on Heterozostera tasmanica was much greater under 91 to $98 \%$ shade than under 65 to $75 \%$ shade (Bulthuis 1983). Gordon et al. (1994) also attributed the faster response of $P$. sinuosa to shading of 80 to $99 \%$ in their study than to $50 \%$ shading in Neverauskas' (1988) study to the difference in light reduction in the 2 studies.

Posidonia australis did not recover from shading stress. After 17 mo without shade, the shoot density had not increased significantly and was still significantly less than in control plots. The shoot density of $P$. sinuosa in Princess Royal Harbour (Albany. Western Australia) was still significantly less than in control areas at the last observation, 8 months after the shades were removed (Gordon et al. 1994). Patches of Posidonia spp. where the rhizomes die after being shaded will probably not recover unless rhizomes grow in from surrounding areas. Such recovery is likely to be very slow, judging by the nonrecovery of areas of seagrass in Jervis Bay which were cleared more than 30 yr ago (pers. obs.). Sexual reproduction cannot be relied upon. to recolonise impacted areas because seedling success is very low (Kirkman, unpubl. data) and shading inhibited flowering of $P$. australis in Jervis Bay. Flowering of Zostera marina (L.) in southern California, USA, was similarly inhibited by shading (Backman \& Barilotti 1976).

The initial response (after $1 \mathrm{mo}$ ) of Posidonia australis to shading in the March to June period was that the leaves grew significantly slower $(-56 \%)$, but the loss of shoots was not significant $(<20 \%)$. Thus this dramatic decline in leaf growth rates was accompanied by a relatively minor decrease in shoot density. This suggests that a drop in growth rate should be detected before shoots are lost. A dramatic or unseasonal decrease in growth rate could be a useful early warning of stress in this species. Growth rates were significantly lower after 1 mo of shading below $I_{C}$ in Expt 1 . Therefore, activities such as dredging should be managed in such a way that periods of high turbidity are restricted to less than a month at a time. However, growth rates were not measured at other times of year, but shoot loss was greater in other seasons, suggesting that turbidity levels and growth rates should be monitored carefully during the first month.

Leaf growth in winter may be critical for the seagrass to produce a large leaf area to maximise growth in the increasing light levels in spring and summer (Pirc 1985). The consequences of shading, in terms of the seagrass' ability to recover, may also be serious in winter. Recovery from shading stress relies on the resumption of normal photosynthetic activity after return to normal light. In winter, when growth rates are reduced, recovery rates may also be reduced (Gordon et al. 1992). Detecting decreases in growth due to shading may be more difficult in winter as the rate decreases naturally, and leaf growth may rely heavily on rhizome reserves (Masini et al. 1995), such that the difference between the shaded and unshaded rates is smaller. Therefore, shoot density may be a useful tool 
for monitoring the adverse effects of shading in Posidonia australis meadows during winter. However, decreases in $P$. australis shoot density may indicate more severe impacts, and our results suggest that there may be a lag period where shoot densities would continue to fall even if the cause of the shading were removed immediately. Detecting a significant decrease in shoot densities would therefore necessitate more rapid management responses. We recommend monitoring leaf growth rates and shoot densities. Leaf growth can provide an early warning of decline, but if decreases go undetected (due to insufficient power in the monitoring program to detect small changes against the background variability), loss of shoots should be detected.

Future experiments on shading Posidonia spp. should assess the effects of light levels above $I_{c}$ but below $I_{k}$, further investigate the influence of season on shading response and rhizome reserve status, taking into account interannual variation, and monitor recovery from stress when growth has been reduced but before many shoots have died. Differences between species could also be better elucidated through experiments in meadows where the 2 species coexist.

Acknowledgements. This study was funded by the Australian Department of Defence, as part of the Jervis Bay Baseline Studies. We thank Richard Timms, Keith Saunders, Fiona Mandelc, Lani Retter and Fiona Whittles for field and laboratory assistance and Carol Conacher, Bill Dennison, Charles Jacoby, Trevor Ward and 3 anonymous referees for constructive discussions or critical review of the manuscript.

\section{LITERATURE CITED}

Backman TW, Barilotti DC (1976) Irradiance reduction: effects on standing crops of the eelgrass Zostera marina in a coastal lagoon. Mar Biol 34:33-40

Bastyan GR (1986) Distribution of seagrasses in Princess Royal Harbour and Oyster harbour, on the southern coast of Western Australia. Department of Conservation and Environment Technical Series 1, Perth

Beer S, Waisel Y (1982) Effects of light and pressure on photosynthesis in two seagrasses. Aquat Bot 13:331-337

Bulthuis DA (1983) Effects of in situ light reduction on density and growth of the seagrass Heterozostera tasmanica (Martens ex Aschers.) den Hartog in Western Port Bay, Victoria, Australia. J exp mar Biol Ecol 67:91-103

Bulthuis DA (1.984) Control of the seagrass Heterozostera tasmanica by benthic screens. J aquat Plant Manage 22: $41-43$

Cambridge ML (1979) Cockburn Sound environmental study technical report on seagrass. Department of Conservation and Environment Report 7. June 1979, Perth

Cambridge ML, Chiffings AW, Brittan C, Moore L, McComb AJ (1986) The loss of seagrass in Cockburn Sound, Western Australia. II. Possible causes of seagrass decline. Aquat Bot 24:269-285

Cochran WG, Cox GM (1957) Experimental designs John Wiley and Sons, Inc., New York

Congdon RA, McComb AJ (1979) Productivity of Ruppia: sea- sonal changes and dependence on light in an Australian estuary. Aquat Bot 6:121-132

CSIRO (1994) Water quality. In: Jervis Bay baseline studies, final report, May 1994. CSIRO Division of Fishenes, North Beach, Western Australia, p 657-773

Dennison WC (1987) Effects of light on seagrass photosynthesis, growth and depth distribution. Aquat Bot 27:15-26

Dennison WC (1990) Leaf production. In: Phillips RC, McRoy CP (eds) Seagrass research methods. UNESCO Monogr oceanogr Methodol 9:77-79

Dennison WC, Alberte RS (1982) Photosynthetic responses of Zostera marina L. (eelgrass) to in situ manipulations of light intensity. Oecologia 55:137-144

Dennison WC, Alberte RS (1985) Role of daily light period in the depth distribution of Zostera marina (eelgrass). Mar Ecol Prog Ser 25:51-61

Fourqurean JW, Zieman JC (1991) Photosynthesis, respiration and whole plant carbon budget of the seagrass Thalassia testudinum. Mar Ecol Prog Ser 69:161-170

Giesen WBJT, van Katwijk MM, den Hartog C (1990a) Temperature, salinity, insolation and wasting disease of eelgrass (Zostera marina L.) in the Dutch Wadden Sea in the 1930's. Neth J Sea Res 25(3):395-404

Giesen WBJT, van Katwijk MM, den Hartog C (1990b) Eelgrass condition and turbidity in the Dutch Wadden Sea. Aquat Bot 37:71-85

Gordon DM, Grey KA, Chase SC, Simpson CJ (1992) Imposed in situ shading and recovery in a Posidonia sinuosa seagrass meadow in Princess Royal Harbour, Western Australia. Environmental Protection Authority Technical Series No 35, Perth

Gordon DM, Grey KA, Chase SC, Simpson CJ (1994) Changes to the structure and productivity of a Posidonia sinuosa meadow during and after imposed shading. Aquat Bot 47:265-275

Gordon DM, McComb AJ (1989) Growth and production of the green alga Cladophora montagneana in a eutrophic Australian estuary and its interpretation using a computer program. Water Res 23(5):633-645

King RJ, Holland VM (1986) Aquatic angiosperms in coastal saline lagoons of New South Wales. II. The vegetation of Tuggerah Lakes, with specific comments on the growth of Zostera capricorni Ascherson. Proc Linn Soc NSW 109(1):25-39

Kirkman H, Kuo J (1990) Pattern and process in southern Western Australian seagrasses. Aquat Bot 37:367-382

Kirkman H, Reid DD (1979) A study of the role of the seagrass Posidonia australis in the carbon budget of an estuary. Aquat Bot 7:173-183

Kuo J, McComb AJ (1979) Seagrass taxonomy, structure and development. In: Larkum AWD, McComb A, Shepherd SA (eds) Biology of seagrasses: a treatise on the biology of seagrasses with special reference to the Australian region. Elsevier, Amsterdam, p 6-73

Larkum AWD, den Hartog C (1989) Evolution and biogeography of seagrasses. In: Larkum AWD, McComb A, Shepherd SA (eds) Blology of Seagrasses: a treatise on the biology of seagrasses with special reference to the Australian region. Elsevier, Amsterdam, p 112-156

Libes $M$. Boudouresque CF (1987) Uptake and long-distance transport of carbon in the marine phanerogram Posidonia oceanica. Mar Ecol Prog Ser 38:177-186

Masini RJ, Cary JL, Simpson CJ, McComb AJ (1990) Effects of light and temperature on the photosynthesis of seagrasses, epiphytes and macroalgae and implications for management of the Albany Harbours. Environmental Protection Authority, Technical Series 32, Perth, Western Australia 
Masini RJ, Cary JL, Simpson CJ, McComb AJ (1994) Effects of light and temperature on the photosynthesis of temperate meadow-forming seagrasses in Western Australia. Aquat Bot 44(4)239-254

Neverauskas VP (1987) Monitoring seagrass beds around a sewage sludge outfall in South Australia. Mar Pollut Bull 18:158-164

Neverauskas VP (1988) Response of a Posidonia community to prolonged reduction in light. Aquat Bot 31:361-366

Onuf CP (1994) Seagrasses, dredging and light in Laguna Madre, Texas, USA. Estuar Coast Shelf Sci 39:75-91

Pirc H (1985) Growth dynamics in Posidonia oceanica (L.) Delile I. Seasonal changes of soluble carbohydrates, starch, free amino acids, nitrogen and organic anions in different parts of the plant. PSZN I: Mar Ecol 6(2):141-165

This article was presented by G.W. Thayer (Senior Editorial Advisor), Beaufort, N. Carolina, USA
Rogers CS (1990) Responses of coral reefs and reef organisms to sedimentation. Mar Ecol Prog Ser 62:185-202

Shepherd SA, McComb AJ, Bulthuis DA, Neverauskas V, Steffenson DA, West $R$ (1989) Declines of seagrasses. In: Larkum AWD, McComb A, Shepherd SA (eds) Biology of Seagrasses: a treatise on the biology of seagrasses with special reference to the Australian region. Elsevier, Amsterdam, p 346-393

Silberstein K, Chiffings AW, McComb AJ (1986) The loss of seagrass in Cockburn Sound, Western Australia. III. The effect of epiphytes on productivity of Posidonia australis. Hook f. Aquat Bot 24:355-371

West RJ, Thorogood C, Walford T, Williams RJ (1985) An estuarine inventory for New South Wales, Australia. Fisheries Bulletin 2, Department of Agriculture, Sydney

Manuscript first received: September 23, 1994

Revised version accepted: April 21, 1995 